\title{
Solid state and sub-cooled liquid vapour pressures of substituted dicarboxylic acids using Knudsen Effusion Mass Spectrometry (KEMS) and Differential Scanning Calorimetry
}

\author{
A. M. Booth ${ }^{1}$, M. H. Barley ${ }^{1}$, D. O. Topping ${ }^{1}$, G. McFiggans ${ }^{1}$, A. Garforth ${ }^{2}$, and C. J. Percival ${ }^{1}$ \\ ${ }^{1}$ School of Earth, Environmental and Atmospheric Science, University of Manchester, UK \\ ${ }^{2}$ School of Chemical Engineering and Analytical Science, University of Manchester, UK
}

Received: 18 February 2010 - Published in Atmos. Chem. Phys. Discuss.: 26 February 2010

Revised: 12 May 2010 - Accepted: 18 May 2010 - Published: 26 May 2010

\begin{abstract}
Solid state vapour pressures of a selection of atmospherically important substituted dicarboxylic acids have been measured using Knudsen Effusion Mass Spectrometry (KEMS) over a range of $20 \mathrm{~K}(298-318 \mathrm{~K})$. Enthalpies of fusion and melting points obtained using Differential Scanning Calorimetry (DSC) were used to obtain sub-cooled liquid vapour pressures. They have been compared to estimation methods used on the E-AIM website. These methods are shown to poorly represent $-\mathrm{OH}$ groups in combination with $\mathrm{COOH}$ groups. Partitioning calculations have been performed to illustrate the impact of the different estimation methods on organic aerosol mass compared to the use of experimental data.
\end{abstract}

\section{Introduction}

\subsection{Organic aerosols}

Atmospheric aerosols influence climate directly via the scattering, reflection and absorption of solar radiation, and indirectly by acting as cloud condensation nuclei. The errors associated with aerosols are one of the greatest uncertainties in our understanding of radiative forcing (Solomon et al., 2007). Organic components comprise a major fraction of the sub-micron particulate mass in the ambient lower atmosphere in all locations where they have been sampled (Zhang

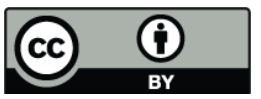

Correspondence to: A. M. Booth (alastair.booth@manchester.ac.uk) et al., 2007; Hallquist et al., 2009). The organic fraction may comprise many tens to hundreds of thousands of compounds (Goldstein and Galbally, 2007). A significant proportion of these components are thought to arise from gas to particle partitioning, as opposed to primary particulate emissions.

\subsection{Vapour pressures}

Organic aerosol (OA) formation from volatile organic compounds (VOC) is frequently described by an equilibrium based absorptive partitioning model (Barley et al., 2009; Pankow et al., 1994). This requires knowledge of pure component vapour pressures. There are many methods of estimating pure component vapour pressures but most of the experimental data collected to date has been for intermediate or high vapour pressures and the proportion of experimental data for low vapour pressures $(<100 \mathrm{~Pa})$ has been very small. Some of the estimation methods can give errors in vapour pressure of several orders of magnitude for multifunctional compounds at ambient temperatures (Makar, 2001; Camredon et al., 2006; Pankow and Asher, 2008; Barley and McFiggans, 2010). The testing of vapour pressure estimation methods for use in atmospheric applications is severely limited by the relatively small number of multifunctional compounds for which experimental vapour pressure are available at ambient temperatures. This requires a reliable method of determining vapour pressures of low volatility compounds at ambient temperatures. Knudsen Effusion Mass Spectrometry (KEMS) is a well-established technique for measuring the vapour pressures of very low volatility compounds at high temperatures (up to $2500 \mathrm{~K}$ ) such as metals and ceramics

Published by Copernicus Publications on behalf of the European Geosciences Union. 
(Hilpert, 1991, 2001). It has also recently been used to measure the solid state vapour pressure at ambient temperature of straight chain dicarboxylic acids; oxalic, malonic, succinic, glutaric and adipic acid (Booth et al., 2009a). Carboxylic acids have been well established as components of atmospheric aerosols (Kawamura and Kaplan, 1987; Bilde et al., 2003; Cappa et al., 2007; Kundu et al., 2010), although there is a high level of uncertainty in the formation mechanisms of multifunctional oxygenated organics (Hallquist et al., 2009). Substituent functional groups of dicarboxylic acids have been isolated and identified in laboratory SOA studies and atmospheric aerosols; methyl (Sempere and Kawamura, 1994) keto (Kawamura et al., 1996) and alcohol (Gao et al., 2003; Kawamura et al., 2005) have all been observed. Understanding how such groups affect vapour pressure is therefore important.

\subsection{Sub-cooled liquid vapour pressures}

These dicarboxylic acids are solids at room temperature and pressure, however, in the atmosphere they can exist as components of a sub-cooled liquid aerosol (Riipinen et al., 2007; Koponen et al., 2007). The sub-cooled liquid is the metastable liquid which exists if solidification does not occur at temperatures below that of the triple point. On a $P, T$ phase diagram it is a line that forms an extension to the liquid phase vapour pressure line below the triple point temperature. Additionally, current gas/particle partitioning models use the sub-cooled reference state, as do activity models. The sub-cooled liquid vapour pressure therefore allows easier comparison with theoretical vapour pressure estimation methods which predict the sub-cooled state. KEMS however cannot directly measure the sub-cooled liquid vapour pressure. The solid state vapour pressure can be corrected to the sub-cooled state value using thermochemical properties obtained by other means such as Differential Scanning Calorimetry (DSC) (Prausnitz et al., 1986). In this work we combine results from KEMS and DSC to obtain solid state and sub-cooled liquid vapour pressures for the following diand tri-carboxylic acids: oxalic, malonic, methyl-malonic, tartronic, succinic, malic, tartaric, keto-succinic, methylsuccinic, aspartic, citramalic, glutaric, 2-methyl-glutaric, 3methyl-glutaric, 2-keto-glutaric, 3-keto-glutaric, glutamic, citric and adipic acid.

\section{Theory}

\subsection{Sub-cooled correction}

The sub-cooled vapour pressure is derived from the value measured above the solid state using the following equation (Prausnitz et al., 1986):

$$
\begin{aligned}
& \ln \frac{p_{l}}{p_{s}}=\frac{\Delta H_{\text {fus }}}{R T_{m}}\left(\frac{T_{m}}{T}-1\right)-\frac{\Delta c_{p, s l}}{R}\left(\frac{T_{m}}{T}-1\right) \\
& +\frac{\Delta c_{p, s l}}{R} \ln \frac{T_{m}}{T}
\end{aligned}
$$

where $p_{l} / p_{s}$ is the ratio of vapour pressures with the subscript $s$ referring to the solid and 1 to the sub-cooled liquid phase, $\Delta H_{\text {fus }}$ is the enthalpy of fusion $\left(\mathrm{J} \mathrm{mol}^{-1}\right), \Delta c_{p ; s l}$ denotes the best estimate of the underlying change in heat capacity between the liquid and solid state at the melting point $\left(\mathrm{J} \mathrm{mol}^{-1} \mathrm{~K}^{-1}\right), T$ is the temperature $(\mathrm{K})$ and $T_{m}$ is the melting point $(\mathrm{K})$, which is commonly used instead of the triple point, $T_{t} . T_{m}$ is typically within $1 \mathrm{~K}$ of $T_{t}$ for small organic acids.

\subsection{Vapour pressure estimation}

Many predictive methods exist for vapour pressure. Barley and McFiggans (2010) recently evaluated several methods using a basis set of 45 multifunctional low-volatility compounds for which experimental vapour pressures were available. Here we compare our experimental results with the methods available on the E-AIM (Extended Aerosol Inorganics Model) website, http://www.aim.env.uea.ac.uk/aim/aim. php (Wexler and Clegg, 2002; Clegg et al., 2008). These methods use a normal boiling point $\left(T_{b}\right)$ from which the vapour pressure at the required temperature is extrapolated using a vapour pressure equation (referred to here as the vapour pressure method). The three vapour pressure methods available are the Nannoolal et al. (2008) and the Moller et al. (2008) methods, both with $T_{b}$ by Nannoolal et al. (2004), and the Myrdal and Yalkowsky (1997) method with $T_{b}$ by Stein and Brown (1994). Additionally, boiling points were calculated using the Joback et al. (1987) method (Dortmund data bank) and used with each of the three vapour pressure methods.

\subsubsection{Nannoolal vapour pressure method}

The Nannoolal et al. (2004) estimation method uses group contribution calculations using primary and secondary groups and group interactions (207 groups). It was used to calculate both normal boiling points (Nannoolal et al., 2004) and the slope of the vapour pressure line (Nannoolal et al., 2008). The normal boiling point $T_{b}(\mathrm{~K})$ is given by:

$$
T_{b}=\frac{\sum_{i} N_{i} C_{i}}{n^{a}+b}+c
$$

where $N_{i}$ is the number of groups of type $i, C_{i}$ the group contribution of group $i[\mathrm{~K}]$,

$a, b, c$ are adjustable parameters from a linear regression ( $a=0.6583, b=1.6868, c=84.3395$ ) of the equation to experimental boiling points, and $n$ is the total number of atoms 
in the molecule (except hydrogen). The vapour pressure in atm is given by:

$\log _{10} P_{i}^{0}=(4.1012+d B)\left[\frac{T-T_{b}}{T-0.125 T_{b}}\right]$

where $d B$ adjusts the slope of the vapour pressure curve and is calculated using group contributions.

$d B=\left(\sum N_{i} C_{i}+G I\right)-0.176055$

where the first term in the brackets is the sum of the primary and secondary group contributions, and the second term is the group interaction:

$G I=\frac{1}{n} \sum_{i=1}^{m} \sum_{j=1}^{m} \frac{C_{i-j}}{m-1}$

where $C_{i-j}=C_{j-i}$ and $m, n$ are the total number of interacting groups and the number of (non-hydrogen) atoms in the molecule respectively.

\subsubsection{Moller vapour pressure method}

The Moller et al. (2008) method is a refinement of the Nannoolal et al. (2008) method. It features an additional term to improve predictions for aliphatic alcohols and carboxylic acids, new size dependent groups to improve predictions for several functional groups, and new hydrocarbon groups. Rewriting Eq. (3) and adding the extra term gives:

$\log _{10} P_{i}^{0}=B^{\prime} \frac{T-T_{b}}{T-C\left(T_{b}\right)}+D^{\prime} \ln \left(\frac{T}{T_{b}}\right)$

where $D^{\prime}$ is the the new term for carboxylic acids and alcohols which is set to zero when they are not present. In the Nannoolal et al. (2008) method, $C=T_{b} / 8$, but this is replaced in the Moller et al. (2008) method with the following term:

$C\left(T_{b}\right)=-2.65+\frac{T_{b}^{1.485}}{135}$

All group contributions were refitted to the above equations. Several new hydrocarbon groups were added to account for specific structural effects, and size dependent corrections for alkene and alkyne molecules were also introduced to improve predictions.

\subsubsection{Myrdal and Yalkowsky vapour pressure method}

The Myrdal and Yalkowsky (1997) method requires a source of boiling point $\left(T_{b}\right)$ estimations. In this work the group contribution method of Stein and Brown (1994) (85 groups), which is adapted from an earlier method (Joback and Reid, 1987), was used to provide $T_{b}$. This was then used with the equations of Myrdal and Yalkowsky (1997) which uses the flexibility of the molecular structure and hydrogen bond number to estimate the entropy of vapourisation $\Delta S_{\mathrm{vap}}$ :

$\Delta S_{\text {vap }}=86+0.4 \tau+1421 \times \mathrm{HBN}$ where $\tau$ is the effective number of torsional bonds and HBN is the number of hydrogen bonds. This is then used with a vapour pressure equation:

$$
\begin{gathered}
\log _{10} P_{i}^{0}=-\frac{[56.5-19.2 \log (\sigma)+9.2 \tau]\left(T_{m}-T\right)}{19.1 T} \\
-\frac{\Delta S_{\mathrm{vap}}\left(T_{b}-T\right)}{19.1 T}-\frac{[90.0+2.1 \tau]}{19.1}\left(\frac{T_{b}-T}{T}-\ln \frac{T_{b}}{T}\right)
\end{gathered}
$$

where the $P_{i}^{0}$ is the vapour pressure (Atm) and $\sigma$ is the molecular rotational symmetry number. The first term is a correction between the solid state and sub-cooled liquid vapour pressure, so would only be used when calculating a solid state vapour pressure. If calculating a liquid or subcooled liquid, as with this case, then just the 2nd and 3rd terms are used.

\subsection{Equilibrium gas to aerosol partitioning}

The partitioning model follows the approach described in Barley et al. (2009). This approach is based upon earlier models (Pankow, 1994; Pankow et al., 2001) with minor modification. The semi-volatile compounds are partitioned according to their saturation concentration $\left(C_{i}^{*}\right)$ value:

$C_{i}^{*}=\frac{10^{6} \gamma_{i} P_{i}^{0}}{R T}$

where $P_{i}^{0}$ is the saturated vapour pressure of component $i$ in atmospheres, $\gamma_{i}$ is the activity coefficient of component $i$ and $C_{i}^{*}$ is the saturation concentration in $\mu \mathrm{mol} \mathrm{m}{ }^{-3}$. The amount of condensed material $\left(C_{\mathrm{OA}}\right)$ is then calculated by summing over all components $i$ ensuring the amount of material (moles) are balanced between the two phases for each component considered. Defining a partitioning coefficient $\xi$ for compound i given its saturation concentration $C_{i}^{*}$ :

$\xi_{i}=\left(1+\frac{C_{i}^{*}}{C_{\mathrm{OA}}}\right)^{-1}$

where both $C_{i}^{*}$ and $C_{\mathrm{OA}}$ have units of $\mu \mathrm{mol} \mathrm{m}{ }^{-3}$. The total number of moles of organic aerosol is the sum of the products of the individual component concentrations $\left(C_{i}\right)$ and their partitioning coefficient $\left(\xi_{i}\right)$ :

$C_{\mathrm{OA}}=\sum_{i} C_{i} \xi_{i}$

Equation (2) will thus quantify the amount of each component in the condensed phase in $\mu \mathrm{mol} \mathrm{m}^{-3}$ and is readily converted into mass based amounts by multiplying by the appropriate molecular weight. Summing the mass based condensed quantities for all the compounds provides the amount of total condensed OA in mass based units. 


\section{Experimental}

Samples of oxalic, malonic, methyl-malonic, tartronic, succinic, malic, tartaric, keto-succinic, methyl-succinic, aspartic, citramalic, glutaric, 2-methyl-glutaric, 3-methyl-glutaric, 2-keto-glutaric, 3-keto-glutaric, glutamic, citric and adipic acid were purchased from Sigma-Aldrich with purities of $99 \%$ or higher and used with no further preparation. Solid state vapour pressures were determined using a custom built Knudsen Effusion Mass Spectrometer. Solid state vapour pressures have been previously reported for oxalic, malonic, succinic, glutaric and adipic acid (Booth et al., 2009a) using this KEMS system. The system (Fig. 1) consists of two chambers connected via an all metal gate valve (VAT-valves). Each chamber is separately pumped by $701 \mathrm{~s}^{-1}$ pumping speed V-81-T turbo pumps (Varian) on CF 63 flanges with a SH-110 dry scroll backing pump. Pressure is measured using convectorr gauges (Varian) for atmospheric pressure down to $10^{-3} \mathrm{mbar}$, and IMG-100 inverted magnetron ion gauges for $<10^{-4}$ mbar (Varian).

Briefly, a sample of known vapour pressure is placed in a temperature controlled cell. The cell has a champfered effusing orifice with a size $\leq 1 / 10$ the mean free path of the gas molecules in the cell. This ensures the orifice does not significantly disturb the thermodynamic equilibrium of the samples in the cell (Hilpert, 2001). The resulting molecular beam is ionised by electron impact, then sampled by a Balzers-Pfeiffer quadrupole mass spectrometer which was used with a QMS 410 mass analyzer, a QMH 410 RF-box connected to a QMG 422 controller. This produces a signal proportional to the vapour pressure. After calibration a sample of unknown vapour pressure is put in the cell. During sample change the second chamber is isolated via the gate valve and vented to air allowing the ioniser filament to be left on. After this calibration, unknown vapour pressures can be determined from the intensity of the mass spectrometer signal of the compound in question. The system can be used to determine partial pressures of mixed systems. The pressure of the $i^{\text {th }}$ component in the KEMS instrument $P_{i}$ in Pascals, is given by:

$P_{i}=\frac{k I_{i} T}{\sigma_{i}}$

where $I_{i}$ is the ion intensity measured in the mass spectrometer, $\sigma_{i}$ is the ionisation cross section and $T$ is the temperature of the Knudsen cell in Kelvin. $k$ is the machine constant which incorporates information on the geometry of the system, Clausing factor of the effusion orifice and any other correction factors, and is determined by using reference samples of known vapour pressure. $\sigma_{i}$ is calculated by summing the ionisation cross section from constituent atoms or groups in the molecule at the ionisation energy $(70 \mathrm{eV})$ (Hilpert, 2001) using data obtained from the NIST electron impact database (Kim and Irikura, 2000). In all cases, the accommodation coefficient is assumed to be identical between samples. Such an

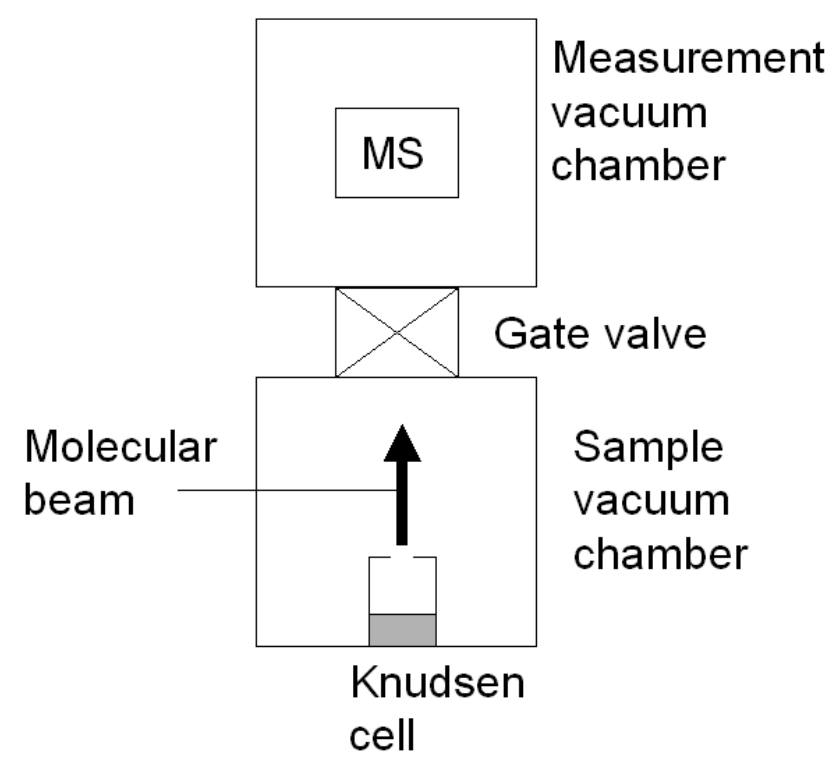

Fig. 1. Schematic of KEMS system. Reproduced from Booth et al. (2009a).

assumption may introduce unquantifiable errors, but it is expected that they are minimized by appropriate choice of similar reference and sample compounds (Booth et al., 2009a). KEMS directly measures the steady state vapour pressure but the equilibrium vapour pressure is desired. If the Knudsen number is high enough then effusing gas does not significantly disturb the equilibrium in the cell (Booth et al., 2009a; Hilpert, 1991, 2001) making the steady state pressure measured as close as possible to equilibrium conditions (negligible perturbation of condensation/evaporation equilibrium). There was no systematic difference between hole size for the dicarboxylic acid measurements made using this system in Booth et al. (2009a), so the assumption that the steady state vapour pressure is indistinguishably close to the equilibrium vapour pressure is valid. Pressures reported are the average of two runs. Based on repeat runs of several compounds over a temperature range of $20 \mathrm{~K}$ we estimate the error to be $\pm 40 \%$. Enthalpies and entropies of sublimation were obtain from a linear fit of the Clausius-Clapeyron equation with estimated errors based on Booth et al. (2009a) of $\pm 15 \%$.

Melting points $\left(T_{m}\right)$ and Enthalpies of Fusion $\left(\Delta H_{\text {fus }}\right)$ were measured using a TA instruments Q200 Differential Scanning Calorimeter (DSC). Heat flow and temperature were calibrated using an indium reference, and heat capacity using sapphire reference. A heating rate of $10 \mathrm{C} \mathrm{min}^{-1}$ was used. 5-10 mg of sample was measured out and recorded using a microbalance, the sample was then pressed into a hermetically sealed aluminium DSC pan. A purge gas of $\mathrm{N}_{2}$ was used with a flow rate of $30 \mathrm{ml} \mathrm{min}^{-1}$. The reference was an empty sealed pan of the same type. Data processing was performed using the "Universal Analysis" software 


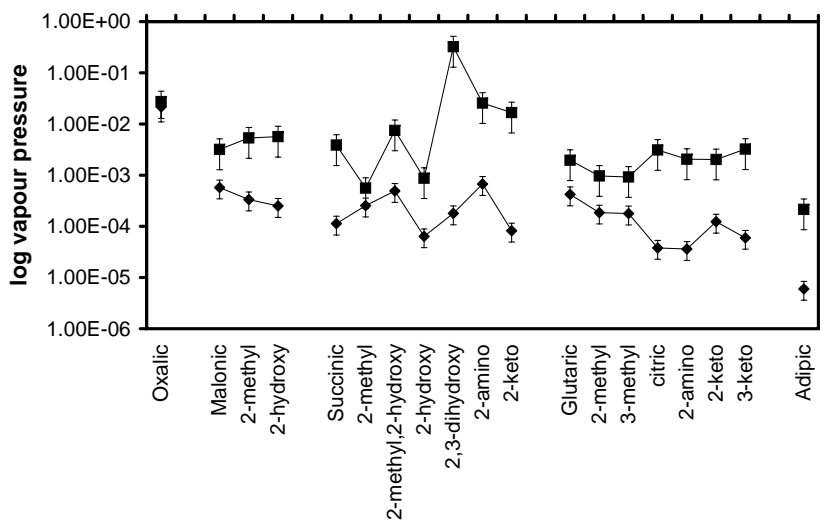

Fig. 2. Vapour pressures in Pa at 298 K. solid state, $\mathbf{\square}$ sub-cooled liquid.

supplied with the instrument. $\Delta c_{p, s l}$ is frequently estimated using three assumptions, based on empirical evidence; $\Delta c_{p, s l}=0$ (Yalkowsky et al., 1981; Prausnitz et al., 1986), $\Delta c_{p, s l}=0.5 \Delta S_{\text {fus }}$ (Tsonopoulos, 1970) and $\Delta c_{p, s l}=\Delta S_{\text {fus }}$ (Mauger et al., 1972; Grant et al., 1984) which is used in this work.

\section{Results and discussions}

\subsection{Solid state vapour pressures}

The dependency of certain solid state properties, such as solubility (Booth et al., 2009b) or sublimation pressure (Booth et al., 2009a; Bilde et al., 2003), of dicarboxylic acids on carbon chain parity is well known and has been attributed to crystalline structure. Hydrogen bonds formed from carboxylic end groups line up with neighbouring molecules in either a cis- (Odd) or trans- (Even) configuration which makes the crystal structure less or more stable, respectively. Interestingly this property also influences the effect of substitutions on the carbon chain. For diacids with an odd carbon number and a relatively less stable crystal structure, the addition of extra groups seems to always lower the vapour pressure (Fig. 2, Table 1). A factor of $\sim 0.5$ for methyl-malonic and tartronic compared to malonic, and 0.4 to 0.1 for glutaric depending on the group. With succinic acid (an even carbon number) most group additions raise the solid state vapour pressure by factors of 2 to 6 (excepting a single alcohol or ketone group).

Mønster et al. (2004) have studied methyl and dimethyl substituted dicarboxylic acids using a HTDMA system. They also note that additional groups give an increase in solid state vapour pressure for even numbered dicarboxylic acids. They see an even greater increase in solid state vapour pressure from methyl substitutions to succinic acid compared with this work. Knudsen mass loss (da Silva et al., 2001) has also been used to study methyl substitutions (Table 2, Fig. 3). Mass loss data extrapolated down to $298 \mathrm{~K}$ from a higher temperature shows good agreement with our data (within $1 \sigma$, except for methyl malonic which is within $2 \sigma$ ). Frosch et al. (2010) have recently published results on keto substituted diacids using the HTDMA technique (Table 3, Fig. 3). We both observe reductions in the solid state vapour pressure for keto substitutions, including a vapour pressure for 3-keto glutaric $\sim 50 \%$ lower than for 2-keto glutaric. They observe a greater reduction in vapour pressure for all keto substitutions. Although they state that 2-keto succinic and 3-keto glutaric may have undergone decarboxylation, affecting the values. Solubility or surface tension effects could possibly explain the differences in the size of the keto and methyl substitution effects compared to Frosch et al. (2010) and Mønster et al. (2004). Surface tension is a term in the Kohler equation which effects the vapour pressure over the aerosols measured in the TDMA method to derive vapour pressures. Froesch et al. (2010) assume a surface tension of $72.9 \mathrm{mN} / \mathrm{m}^{-1}$ (pure water) in their work, and they also state limited solubility was not accounted for. This hypothesis could be tested by intercomparing the two techniques on both a very soluble compound (e.g. citric acid) and an insoluble, strongly surfactant compound (e.g. pinonic acid).

\subsection{Sub-cooled liquid vapour pressures}

Sub-cooled liquid vapour pressures (Fig. 2) were derived using Eq. (1) and the thermochemical data in Table 4. The oddeven effect is noticeable in the melting point and enthalpy of sublimation of the straight chain diacids. The corrected subcooled liquid vapour pressures for the unsubstituted diacids show no odd-even effect. There is a significant difference, by up to three orders of magnitude, between the two pressures. This arises as a result of the sub-cooled liquid vapour pressure diverging from the solid vapour pressure at the melting point. As the $P_{298} \mathrm{~K}$ is measured at a temperature much lower than $T_{m}$ (A minimum of $71 \mathrm{~K}$ lower for glutaric acid and a maximum of $238 \mathrm{~K}$ for the glutamic acid estimate) a large difference is expected.

Riipinen et al. (2007) and Koponen et al. (2007) measured vapour pressures in the humidity range $58-80 \%$ and derived values for the sub-cooled liquid state (Table 5, Fig. 4). Our data for those 4 diacids show higher values than those of Riipinen et al. (2007). The discrepancy between our results is far larger at short chain lengths; a factor of 6.5 out for malonic, 4 for succinic, 2 for glutaric, and adipic acid is in agreement within experimental error. The HDTMA method requires a model of the thermodynamic activity, the choice of which will impact upon the results obtained. Riipinen et al. (2007) used Dortmund modified UNIFAC. This may explain the differences observed which seem especially prominent for malonic acid. Koponen et al. (2007) used two different activity models (Dortmund modified UNIFAC and Van Laar), and observed differences between them of two orders of magnitude in the calculated solid state vapour pressure 
Table 1. KEMS determined solid state vapour pressures, enthalpies of sublimation and entropies of sublimation. Estimated maximium error on $P_{298 \text { solid }} \pm 40 \%$.

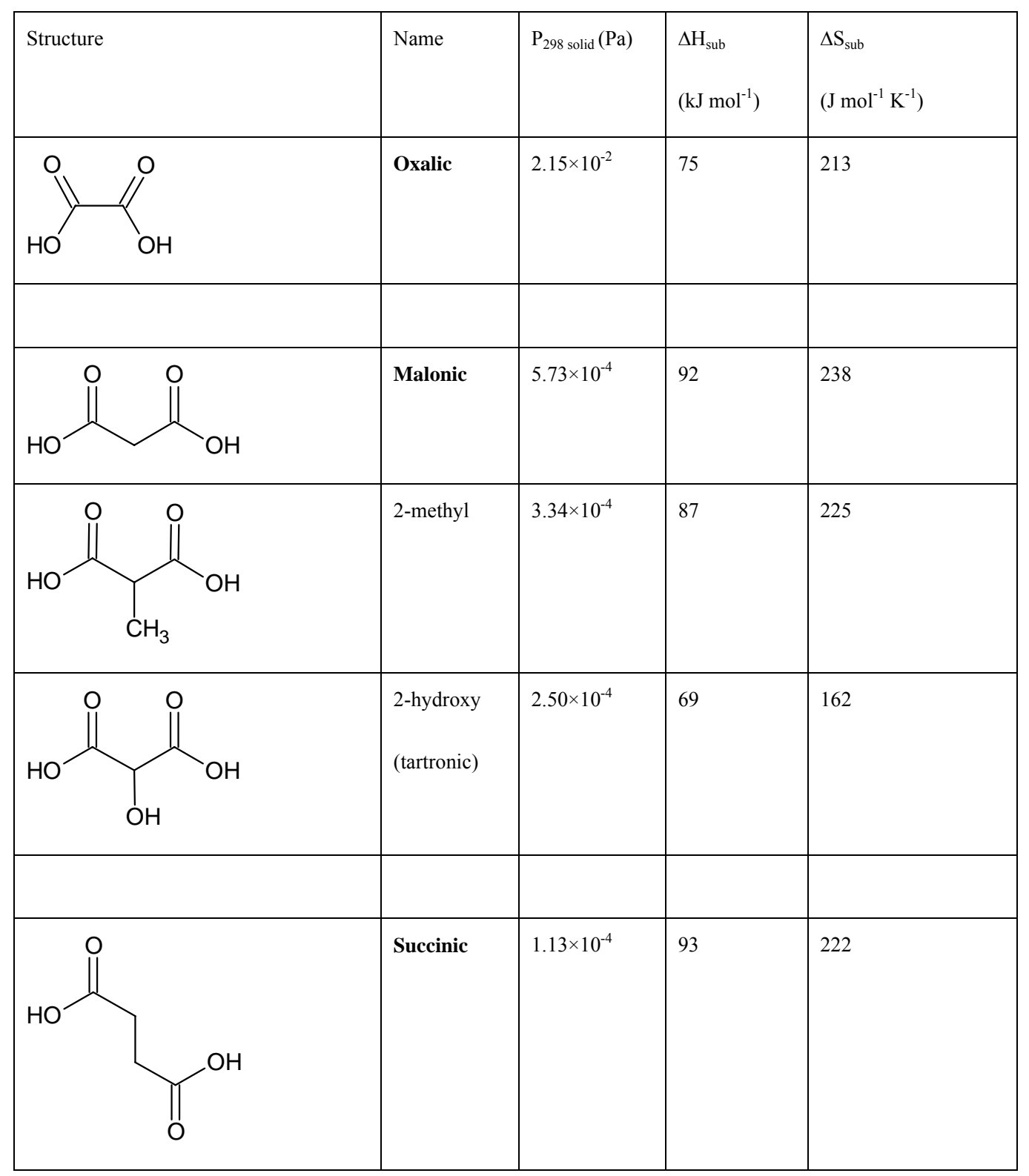

for malonic acid, and the differences between the different activity models decreases with increasing chain length. A comparison of oxalic acid $\left(C_{2}\right)$ could confirm if it is an activity model dependent difference especially prominent for smaller molecules. This opens up the possibility of combining KEMS and TDMA to validate activity models, or if the activity coefficients are known, to evaluate the accommodation coefficients required for the TDMA technique.
Malonic acid shows an increase (factor of $\sim 1.7$ ) in subcooled liquid vapour pressure for methyl and alcohol additions. Glutaric acid shows a decrease by 0.5 for extra methyl groups, amino and keto groups in the 2-position have no discernable effect as the magnitude of the sub-cooled correction cancel out the lower solid state vapour pressure. Interestingly the 3-keto acid and citric acid (an extra $\mathrm{OH}$ and $\mathrm{COOH}$ on the third carbon) show an increase by a factor of 1.6. Succinic acid shows a greater sensitivity to substitutions; single-hydroxy and -methyl groups decrease the vapour pressure (by a factor of $\sim 0.2$ ) but 2-methyl, 2-hydroxy and 
Table 1. Continued.

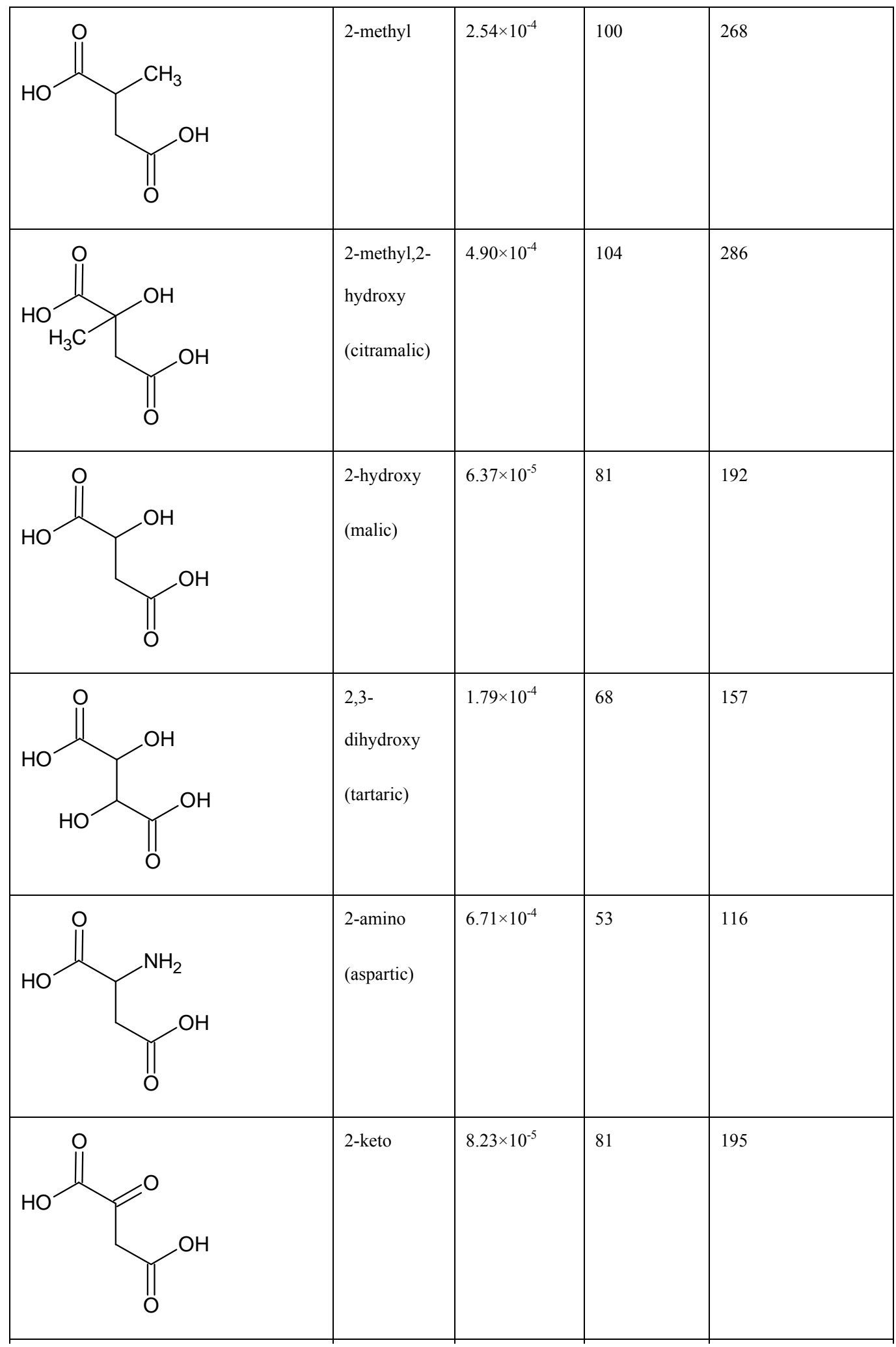


Table 1. Continued.

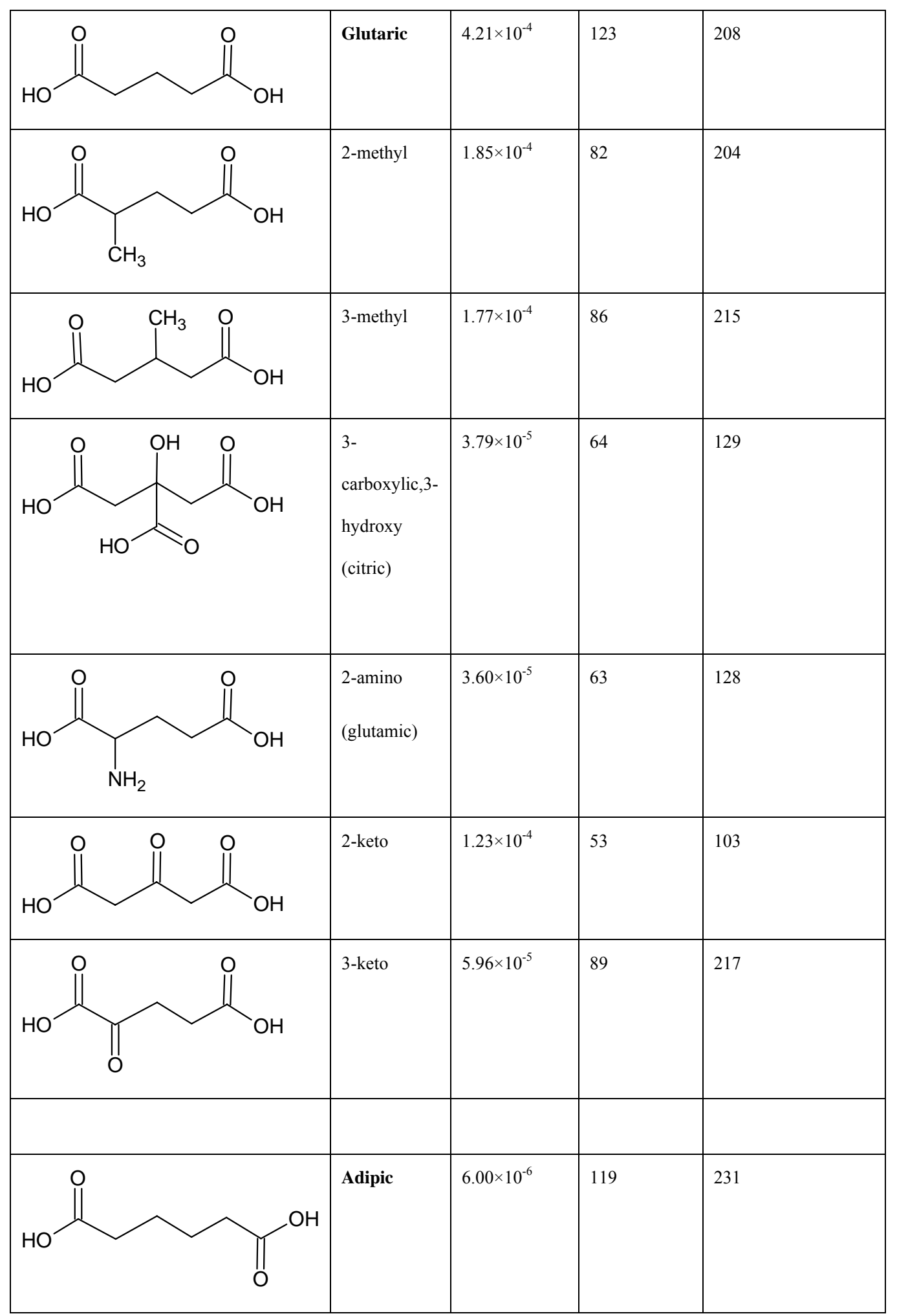


Table 2. Comparison of methyl substituted dicarboxylic acid solid state vapour pressures.

\begin{tabular}{lrrr}
\hline & $\begin{array}{r}P_{298 \text { solid }}(\mathrm{Pa}) \\
\text { this work }\end{array}$ & $\begin{array}{r}P_{298 \text { solid }}(\mathrm{Pa}) \\
\text { Mønster et al. (2004) }\end{array}$ & $\begin{array}{r}P_{298 \text { solid }}(\mathrm{Pa}) \\
\text { da Silva et al. (2001) }\end{array}$ \\
\hline 2-methyl-malonic & $3.34 \pm 1.34 \times 10^{-4}$ & $9.10 \times 10^{-4}$ & $5.70 \times 10^{-4}$ \\
2-methly-succinic & $2.54 \pm 1.01 \times 10^{-4}$ & $1.60 \times 10^{-3}$ & $2.90 \times 10^{-4}$ \\
2-methly-glutaric & $1.85 \pm 0.74 \times 10^{-4}$ & $\mathrm{n} / \mathrm{a}$ & $2.30 \times 10^{-4}$ \\
\hline
\end{tabular}

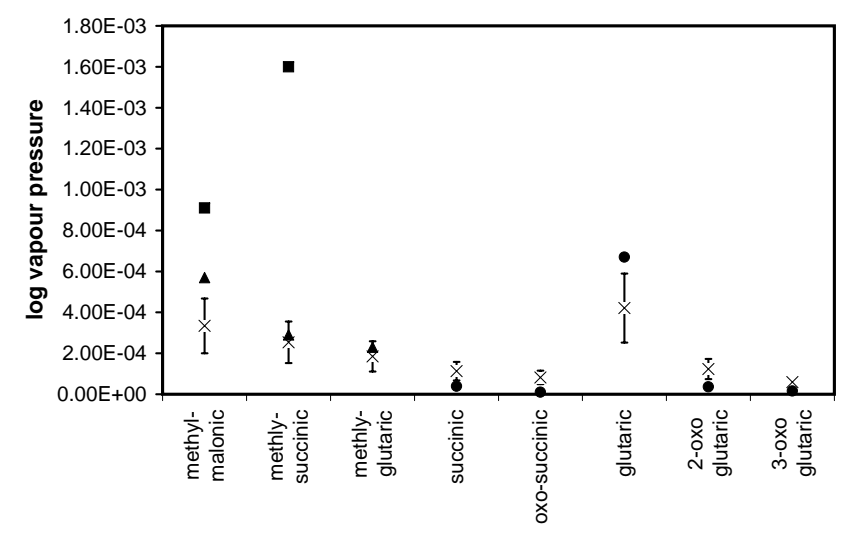

Fig. 3. Comparison of measured solid state vapour pressure at $298 \mathrm{~K}$ in Pa with literature values. Symbols; $\times$ KEMS, $\Delta$ Riberio da Silva et al. (2001), Froesch et al. (2010), $\mathbf{\square}$ Mnster et al. (2003). Froesch et al. (2010) suggest that 2-keto succinic and 3-keto glutaric acid may have undergone decarboxylation affecting their results.

Table 3. Comparison of keto substituted dicarboxylic acid solid state vapour pressures.

\begin{tabular}{lrr}
\hline & $\begin{array}{r}P_{298 \text { solid }} \\
\text { this work }\end{array}$ & $\begin{array}{r}P_{298 \text { solid }} \\
\text { Frosch et al. }(2010)\end{array}$ \\
\hline succinic & $1.13 \pm 0.452 \times 10^{-4}$ & $3.90 \times 10^{-5}$ \\
keto succinic & $8.23 \pm 3.29 \times 10^{-5}$ & $1.00 \times 10^{-5}$ \\
glutaric & $4.21 \pm 1.72 \times 10^{-4}$ & $6.70 \times 10^{-4}$ \\
2-keto glutaric & $1.23 \pm 0.49 \times 10^{-4}$ & $3.60 \times 10^{-5}$ \\
3-keto glutaric & $5.96 \pm 2.38 \times 10^{-5}$ & $1.60 \times 10^{-5}$ \\
\hline
\end{tabular}

2,3-dihydroxy substitutions show increases by a factor of 2 and 80 respectively. 2-amino and 2-keto also show an increased vapour pressure with respect to succinic acid, by factors of 6.6 and 4 respectively. Increasing vapour pressure by adding polar groups is a counter intuitive result. Chattopadhyay and Ziemann (2005) have used thermal desorption particle beam mass spectrometry to obtain solid state vapour pressures of hydroxy-substituted carboxylic and dicarboxylic acids and observe similar effects. They note that group position is highly important; for glutaric acid they observe a 2-hydroxy substitution increasing the vapour pressure by a

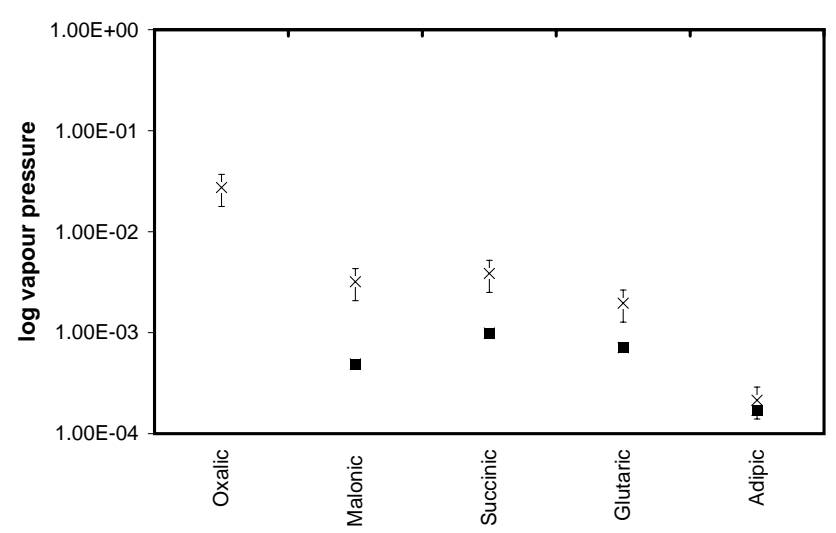

Fig. 4. Comparison of sub-cooled liquid vapour pressure at $298 \mathrm{~K}$ in Pa. Symbols; $\times$ KEMS, $\square$ Riipinen et al. (2007).

factor of 4, and 3-hydroxy substitution decreasing the vapour pressure by a factor of 66. Adipic and azelaic hydroxy substitutions were shown to have similar positional effects. Two possible reasons for the unusual behavior of additional polar groups are; intra-molecular hydrogen bonding between the extra group and one of the carboxylic acid groups (Chattopadhyay and Ziemann, 2005), or an inductive effect reducing the polarity of the acid group. Either could reduce intermolecular bonding and raise the vapour pressure.

The thermochemical parameters used in Eq. (1) determine the difference between the two states. In the literature, reported $T_{m}$ values lie within a range of $4 \mathrm{~K}$ for malonic and succinic, and $7 \mathrm{~K}$ for glutaric and adipic. The extremes of these values give differences of 5\% and $12 \%$ respectively for the sub-cooled liquid vapour pressure. Similarly, $\Delta H_{\text {fus }}$ values lie in a range of $\sim 7 \mathrm{~kJ} \mathrm{~mol}^{-1}$ for malonic and adipic and $\sim 4 \mathrm{~kJ} \mathrm{~mol}^{-1}$ for succinic and glutaric; leading to variations of up to $80 \%$ and $40 \%$ respectively. The assumption of $\Delta c_{p ; s l}=\Delta S_{\text {fus }}$ leads to an differences in the sub-cooled liquid vapour pressure, compared with literature values, of $\sim 10-20 \%$. Combining this with the uncertainties in the solid state vapour pressure ( $\sim 40 \%)$ we estimate a maximum uncertainty of $\pm 75 \%$ for our sub-cooled liquid vapour pressures. The sub-cooled liquid vapour pressure diverges from the solid state at the melting point, so it is expected that the higher $T_{m}$ is, the greater the correction. This does however 
Table 4. Sub-cooled liquid vapour pressures, melting points, enthalpies and entropies of fusion. * denotes thermochemical data was unobtainable, Joback et al. (1987) estimates were used instead. Estimated maximum error on $P_{298 \text { sub-cooled }} \pm 75 \%$.

\begin{tabular}{lrrrr}
\hline & $\begin{array}{r}P_{298 \text { sub-cooled }}(\mathrm{Pa}) \\
\text { Oxalic }\end{array}$ & $\begin{array}{r}T_{m} \\
(\mathrm{~K})\end{array}$ & $\begin{array}{r}\Delta H_{\text {fus }} \\
\left(\mathrm{J} \mathrm{mol}^{-1}\right)\end{array}$ & $\begin{array}{r}\Delta S_{\text {fus }} \\
\left(\mathrm{J} \mathrm{mol}^{-1} \mathrm{~K}^{-1}\right)\end{array}$ \\
Malonic & $2.74 \times 10^{-2}$ & 370 & 3424 & 9 \\
2-methyl & $3.19 \times 10^{-3}$ & 406 & 18739 & 46 \\
2-hydroxy & $5.34 \times 10^{-3}$ & 403 & 30746 & 76 \\
Succinic & $5.64 \times 10^{-3}$ & 428 & 30619 & 72 \\
2-methyl & $3.86 \times 10^{-3}$ & 458 & 31259 & 68 \\
2-methyl,2-hydroxy & $7.48 \times 10^{-3}$ & 379 & 35697 & 26 \\
2-hydroxy & $8.72 \times 10^{-4}$ & 403 & 29031 & 94 \\
2,3-dihydroxy & $3.23 \times 10^{-1}$ & 480 & 62723 & 72 \\
2-amino & $2.56 \times 10^{-2}$ & 524 & $28076 *$ & 131 \\
2-keto & $1.67 \times 10^{-2}$ & 437 & 50382 & 114 \\
Glutaric & $1.96 \times 10^{-3}$ & 369 & 22043 & 115 \\
2-methyl & $9.63 \times 10^{-4}$ & 349 & 30259 & 60 \\
3-methyl & $9.19 \times 10^{-4}$ & 356 & 27351 & 87 \\
citric & $3.10 \times 10^{-3}$ & 427 & 43455 & 77 \\
2-amino & $2.05 \times 10^{-3}$ & 536 & $30666^{*}$ & 102 \\
2-keto & $2.02 \times 10^{-3}$ & 386 & 34693 & 105 \\
3-keto & $3.22 \times 10^{-3}$ & 397 & 45895 & 90 \\
Adipic & $2.14 \times 10^{-4}$ & 423 & 35891 & 116 \\
\hline & & & & 85 \\
\hline
\end{tabular}

Table 5. Comparison of dicarboxylic acid sub-cooled liquid vapour pressures.

\begin{tabular}{lrr}
\hline & $\begin{array}{r}P_{298 \text { sub-cooled }}(\mathrm{Pa}) \\
\text { this work }\end{array}$ & $\begin{array}{r}P_{298 \text { sub-cooled }(\mathrm{Pa})} \\
\text { Riipinen et al. }(2007)\end{array}$ \\
\hline Oxalic & $2.74 \pm 1.92 \times 10^{-2}$ & $\mathrm{n} / \mathrm{a}$ \\
Malonic & $3.19 \pm 2.23 \times 10^{-3}$ & $4.90 \times 10^{-4}$ \\
Succinic & $3.86 \pm 2.70 \times 10^{-3}$ & $9.90 \times 10^{-4}$ \\
Glutaric & $1.96 \pm 1.37 \times 10^{-3}$ & $7.10 \times 10^{-4}$ \\
Adipic & $2.14 \pm 1.49 \times 10^{-4}$ & $1.70 \times 10^{-4}$ \\
\hline
\end{tabular}

magnify the impact of any errors association with $\Delta H_{\text {fus }}$ or $\Delta C p_{s, l}$. The comparison of malonic, succinic, glutaric and adipic literature values of $T_{m}, \Delta H_{\text {fus }}$ and $\Delta C p_{s, l}$ with ours does not reveal any systematic differences with increasing $T_{m}$. So while the random errors may be higher for high $T_{m}$ compounds we do not expect a systematic error.

\subsection{Vapour pressure estimates}

As many vapour pressure methods are based predominantly on data for more volatile compounds, low-volatility compound data is essential to verify which methods are best suited for atmospheric applications. The subset of vapour pressure estimation methods shown here are those from the E-AIM (Extended Aerosol Inorganics Model) website, http: //www.aim.env.uea.ac.uk/aim/aim.php (Wexler and Clegg, 2002; Clegg et al., 2008). The estimation methods used here first require a boiling point. Barley and McFiggans (2010) found the Nannoolal et al. (2004) boiling points to give the best results when comparing estimated boiling points for those with experimental data for low volatility compounds. In this data set the Nannoolal et al. (2004) and Stein and Brown (1994) boiling points (Table 6) are in fairly good agreement with differences $\sim 10 \mathrm{~K}$ except for citric and tartaric acid (2,3-dihydroxy-succinic acid) where the difference is $\sim 20 \mathrm{~K}$. The Joback et al. (1987) method gives much higher boiling points than those of Nannoolal et al. (2004), an average of $56 \mathrm{~K}$ higher and up to $160 \mathrm{~K}$ for citric acid.

Table 7 and Fig. 5 show the estimated vapour pressures compared with the KEMS measured values. The Moller et al. (2008), Nannoolal et al. (2008) and Myrdal and Yalkowsky (1997) methods give the best results over this range of compounds when combined with Nannoolal (2004) and Stein and Brown (1994) boiling points, on average 1-2 orders of magnitude out. When using Joback et al. (1987) boiling points the Moller et al. (2008) and Nannoolal et al. (2008) methods perform worse, respectively 4 and 3 
Table 6. Normal boiling points by the estimation methods, in K.

\begin{tabular}{lrrr}
\hline & Joback & Nannoolal & $\begin{array}{r}\text { Stein and } \\
\text { Brown }\end{array}$ \\
\hline Oxalic & 536.38 & 529.636 & 520.084 \\
Malonic & 559.30 & 544.60 & 537.30 \\
2-methyl & 581.70 & 548.53 & 543.87 \\
2-hydroxy & 651.00 & 595.02 & 580.91 \\
Succinic & 582.14 & 559.40 & 553.60 \\
2-methyl & 604.58 & 563.54 & 559.80 \\
2-methyl,2-hydroxy & 693.97 & 602.79 & 596.46 \\
2-hydroxy & 673.88 & 607.13 & 594.65 \\
2,3-dihydroxy & 765.62 & 651.83 & 629.01 \\
2-amino & 654.23 & 590.00 & 584.15 \\
2-keto & 636.01 & 593.11 & 582.81 \\
Glutaric & 605.00 & 573.80 & 570.00 \\
2-methyl & 627.46 & 578.06 & 574.84 \\
3-methyl & 627.46 & 578.06 & 574.84 \\
Citric & 862.36 & 700.97 & 680.33 \\
2-amino & 677.11 & 603.44 & 597.69 \\
2-keto & 658.89 & 606.60 & 596.44 \\
3-keto & 658.89 & 606.60 & 596.44 \\
Adipic & 627.9 & 587.9 & 583.5 \\
\hline
\end{tabular}

orders of magnitude out on average. Interestingly the Myrdal and Yalkowsky (1997) method, when combined with Joback et al. (1987) boiling points gives one of the better results, with the overestimating bias of Joback et al. (1997) boiling points being cancelled out by an opposing bias from the vapour pressure method. The main cause of inaccuracy for the Moller et al. (2008) and Nannoolal et al. (2008) methods are the -hydroxy containing compounds, without these they provide the best match to the experimental data. The Moller et al. (2008) specifically includes extra terms for both $\mathrm{COOH}$ and $\mathrm{OH}$ so additional experimental data from these sorts of compounds is more likely to help improve this method more than any other.

\subsection{Partitioning calculation}

In order to assess the impact of estimates of vapour pressures on secondary organic aerosol (SOA) formation, the partitioning calculation method described by Barley and McFiggans (2010); Barley et al. (2009) was used. The base case used the sub-cooled liquid vapour pressure derived from the KEMS with the abundance of all 19 components set to a value which gave $10.6 \mu \mathrm{g} \mathrm{m}^{-3}$ of $\mathrm{OA}$ as in the Barley and McFiggans (2010) study. Figure 6 shows a boxwhisker plot of the effect on OA yield of substituting a single estimated vapour pressure value for each compound, in turn. The boxes show the lower quartile, median and upper quartile, the whiskers are the lowers and highest values

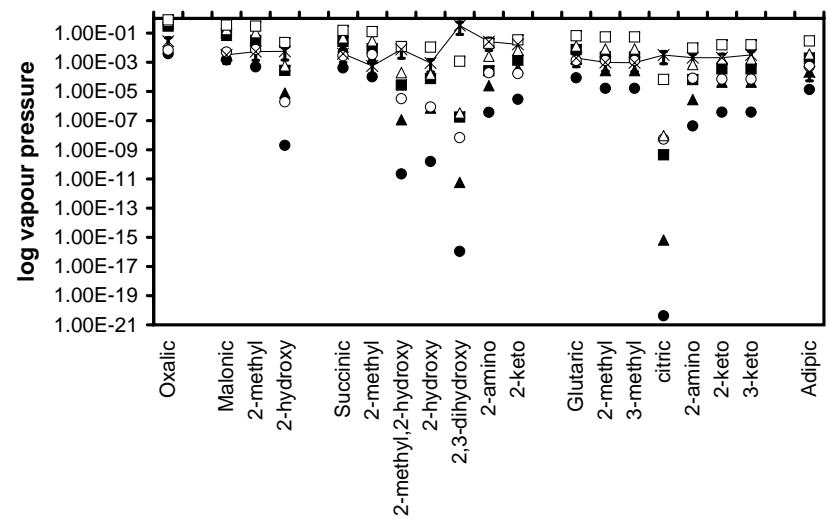

Fig. 5. Sub-cooled liquid vapour pressures in Pa at 298 K. Symbols: $\times$ KEMS; $\bigcirc$ Moller with Nannoolal $T_{b}$; Moller with Joback $T_{b}$; $\square$ Myrdal and Yalkowsky with Stein and Brown $T_{b} ; \mathbf{\square y r d a l}$ and Yalkowsky with Joback $T_{b} ; \Delta$ Nannoolal with Nannoolal $T_{b} ; \Delta$ Nannoolal with Joback $T_{b}$.

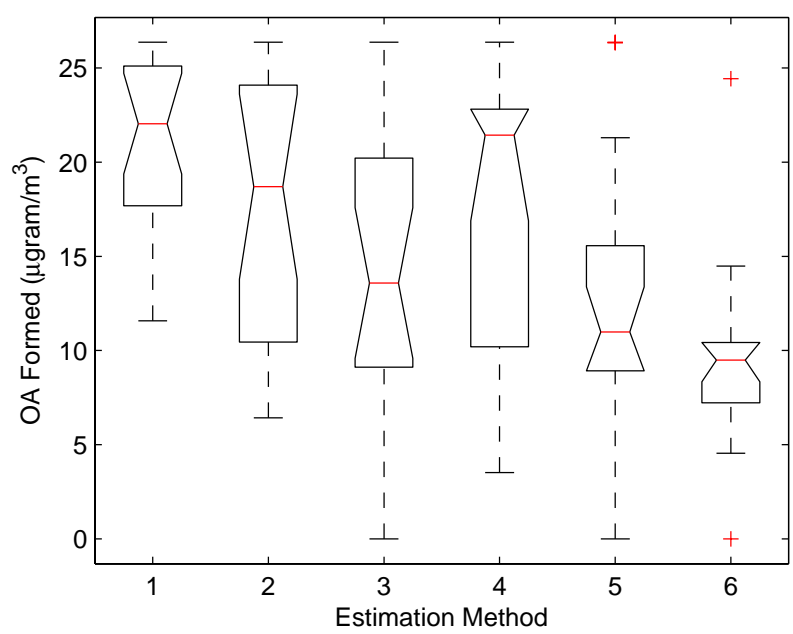

Fig. 6. Box-whisker plots of the predicted amount of OA formed by the partitioning model using estimated vapour pressures for a single compound out of the 19 reported. The boxes show the lower quartile, median and upper quartile, the whiskers are the lowest and highest values within 1.5 times the interquartile range. The base case uses experimental vapour pressure values with the concentration of all components set to the value that gives $10.6 \mu \mathrm{g} \mathrm{m}^{-3}$. Estimation methods are: 1) Moller with Joback $T_{b}$;2) Nannoolal with Joback $T_{b}$; 3) Myrdal and Yalkowsky with Joback $T_{b}$; 4) Moller with Nannoolal $T_{b}$; 5) Nannoolal with Nannoolal $T_{b}$; 6) Myrdal and Yalkowsky with Stein and Brown $T_{b}$.

within 1.5 times the interquartile range, the cross in methods 5 and 6 are the highest or lowest values outside of 1.5 times the interquartile range. As expected, methods using Joback et al. (1987) boiling points tend to overestimate the OA yield, with median overestimates by approximately 12, 8 and $2 \mu \mathrm{g} \mathrm{m}^{-3}$ for Moller et al. (2008), Nannoolal et al. (2008) and Myrdal and Yalkowsky (1997) respectively. 
Table 7. Vapour pressure results for estimation methods, all $P_{298} \mathrm{~K}$ are measured in $\mathrm{Pa}$ in the sub-cooled liquid state. $(\mathrm{J})=\mathrm{J}$ oback et al. (1987) $T_{b},(\mathrm{~N})=$ Nannoolal et al. (2004) $T_{b}$ and (S\&B) = Stein and Brown (1994) $T_{b}$. The experimental data in the final column are measured over a range of $20 \mathrm{~K}$ with maximum errors of $\pm 75 \%$.

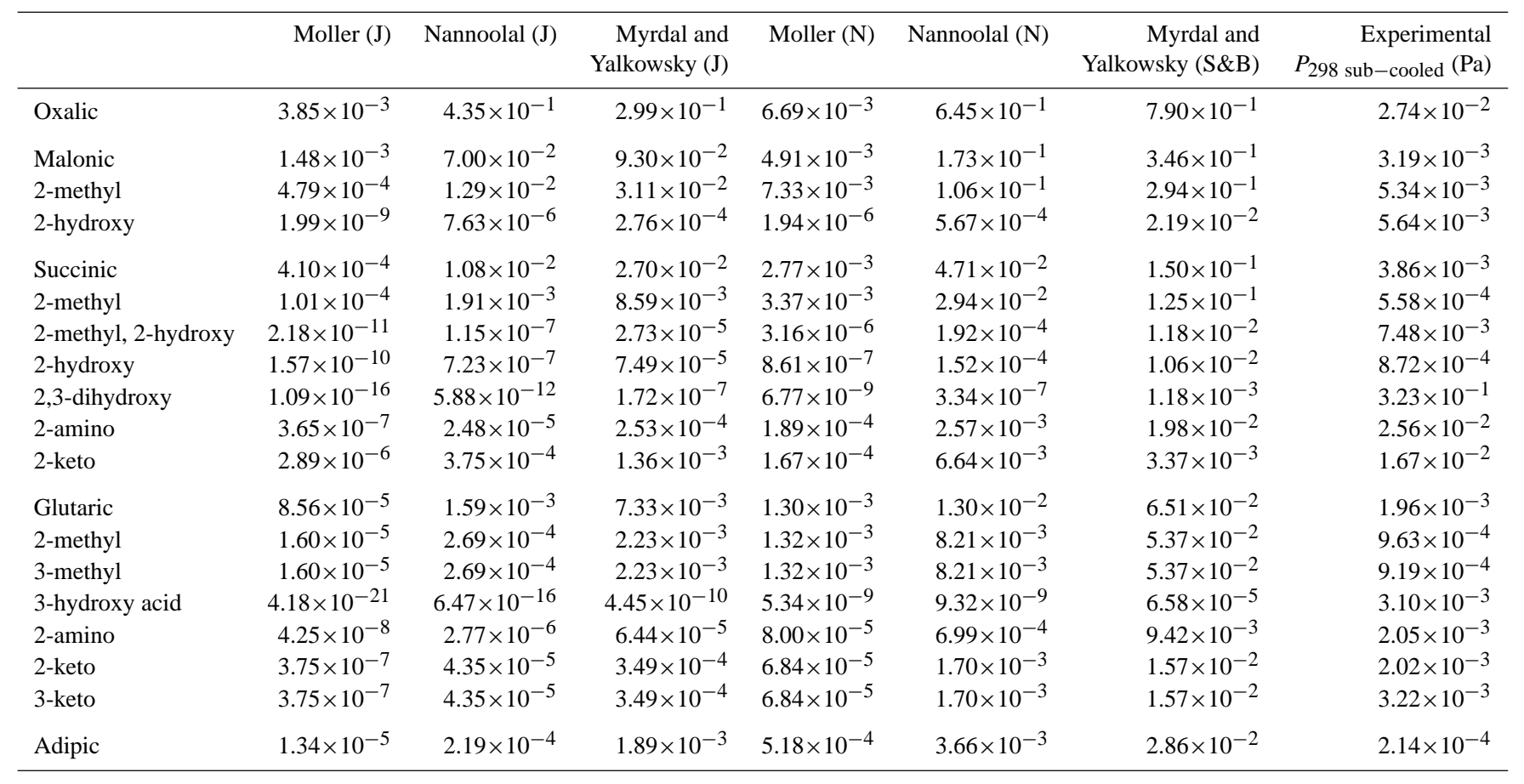

Myrdal and Yalkowsky (1997) with Stein and Brown (1994) boiling points gives the best results with these compounds, with a narrow spread and a median within $1 \mu \mathrm{g} \mathrm{m}^{-3}$ of the target yield. The Nannoolal et al. (2008) method with Nannoolal et al. (2004) boiling points also shows a similar result with the median within $1 \mu \mathrm{g} \mathrm{m}^{-3}$ of the target yield although over a larger range. The Moller et al. (2008) method with Nannoolal et al. (2004) boiling points tends to cause over estimates in the OA yield, with a median value $10 \mu \mathrm{g} \mathrm{m}^{-3}$ greater than the base case, with a very asymmetric spread towards lower OA yields. This will be greatly influenced by this method's tendency to underestimate the vapour pressure of $\mathrm{OH}$ containing compounds.

In order to determine the error propagation, the partitioning calculations have also been performed with the base case increased and decreased by a factor of 1.7 to investigate the most extreme interpretation of our errors on the calculation (in reality they are random errors and would not all be biased in the same direction). This does have a big effect on the total amounts of SOA predicted to form because of normalising the concentration so that the base case gives $10.6 \mu \mathrm{gram} \mathrm{m}^{-3}$ of SOA. With experimental VP values the required concentration is $0.041778 \mu$ moles $\mathrm{m}^{-3}$. If the VP values are all increased by $\times 1.7$ then the required concentration is $0.064116 \mu$ moles $\mathrm{m}^{-3}$ (giving much more SOA with the estimated VP values); while if the experimental VPs are reduced by the same factor the required concentration $\left(0.028194 \mu\right.$ moles $\left.\mathrm{m}^{-3}\right)$ gives much less SOA. The general trends between the estimation methods however remain the same with the Myrdal and Yalkowsky (1997) and Stein and Brown (1994) method still the best in each case followed by the Nannoolal et al. (2008) Nannoolal et al. (2004) method.

\section{Conclusions}

KEMS solid state vapour pressures combined with melting points and enthalpies and entropies of fusion have been used to obtain sub-cooled liquid vapour pressures for a selection of multifunctional compounds based on dicarboxylic acids. The sub-cooled liquid vapour pressures have been compared with a series of vapour pressure estimation methods. The methods underestimate the observed vapour pressure of dicarboxylic acids substituted with hydroxy groups reported in this work, possibly due to intramolecular hydrogen bonding between $\mathrm{COOH}$ and OH groups. Myrdal and Yalkowsky (1997), combined with Stein and Brown (1994) boiling points gives the best estimates. Partitioning calculations illustrate the impact of this for OA yields. The Moller et al. (2008) and Nannoolal et al. (2008) methods with Nannoolal et al. (2004) boiling points do not match the data as closely. They do however include parameters for group interactions, and the Moller et 
al. (2008) method in particular includes extra terms specifically for $\mathrm{COOH}$ and $\mathrm{OH}$ groups. As the interaction between these two groups causes most of the discrepancies, we expect further experimental data will be able to improve this method disproportionately more than any other.

Acknowledgements. The authors thank NERC for financial support on grant NE/E018181/1 and the EU-funded European Integrated project on Aerosol Cloud Climate and Air Quality interactions (EUCAARI) under contract number/break 036833-2.

Edited by: M. Ammann

\section{References}

Barley, M. H. and McFiggans, G.: The critical assessment of vapour pressure estimation methods for use in modelling the formation of atmospheric organic aerosol, Atmos. Chem. Phys., 10, 749767, doi:10.5194/acp-10-749-2010, 2010.

Barley, M., Topping, D. O., Jenkin, M. E., and McFiggans, G.: Sensitivities of the absorptive partitioning model of secondary organic aerosol formation to the inclusion of water, Atmos. Chem. Phys., 9, 2919-2932, doi:10.5194/acp-9-2919-2009, 2009.

Bilde, M., Svenningsson, B., Monster, J. and Rosenorn, T.: Even - Odd Alternation of Evaporation Rates and Vapor Pressures of C3-C9 Dicarboxylic Acid Aerosols, Environ. Sci. Technol., 37, 1371-1378, 2003.

Booth, A. M., Markus, T., McFiggans, G., Percival, C. J., Mcgillen, M. R., and Topping, D. O.: Design and construction of a simple Knudsen Effusion Mass Spectrometer (KEMS) system for vapour pressure measurements of low volatility organics, Atmos. Meas. Tech., 2, 355-361, doi:10.5194/amt-2-355-2009, 2009a.

Booth, A. M., Topping, D. O., McFiggans, G., and Percival, C. J.:, Surface tension of mixed inorganic and dicarboxylic acid aqueous solutions at $298.15 \mathrm{~K}$ and their importance for cloud activation predictions, Phys. Chem. Chem. Phys., 11, 8021-8028, 2009b.

Camredon, M. and Aumont, B.: Assessment of vapor pressure estimation methods for secondary organic aerosol modeling, Atmos. Environ., 40, 2105-2116, 2001.

Cappa, D. C., Lovejoy, E. R., and Ravishankara, A. R.: Determination of Evaporation Rates and Vapor Pressures of Very Low Volatility Compounds: A Study of the $C_{4}-C_{10}$ and $C_{12}$ Dicarboxylic Acids, J. Phys. Chem., 111, 3099-3109, 2007.

Chattopadhyay, S. and Zieman, P. J.: Vapor pressures of substituted and unsubstituted monocarboxylic and dicarboxylic acids measured using an improved thermal desorption particle beam mass spectrometry method, Aerosol Sci. Technol., 39, 10851100, 2005.

Clegg, S. L., Kleeman, M. J., Griffin, R. J., and Seinfeld, J. H.: Effects of uncertainties in the thermodynamic properties of aerosol components in an air quality model - Part 2: Predictions of the vapour pressures of organic compounds, Atmos. Chem. Phys., 8, 1087-1103, doi:10.5194/acp-8-1087-2008, 2008.

Frosch, M., Zardini, A. A., Platt, S. M., Mller, L., Reinnig, M.C., Hoffmann, T., and Bilde, M.: Thermodynamic properties and cloud droplet activation of a series of oxo-acids, Atmos. Chem. Phys. Discuss., 10, 3755-3805, doi:10.5194/acpd-103755-2010, 2010.
Gao, S., Keywood, M., Ng, N. L., Surratt, J., Varutbangkul, V., Bahreini, R., Flagan, R.C., and Seinfeld, J. H.: LowMolecular Weight and Oligomeric Components in Secondary Organic Aerosol from the Ozonolysis of Cycloalkenes and $\alpha$ Pinene, J. Phys. Chem. A., 108, 10147-10164, 2004.

Goldstein, A. H. and Galbally, I. E.,: Known and Unexplored Organic Constituents in the Earth's Atmosphere, Environ. Sci. Technol., 41, 1514-1521, 2007.

Grant, D. J. W., Mendizadeh, M., Chow, A. H.-L., and Fairbrother, J. E.: Non-linear van Hoff Solubility Temperature Plots and their Pharmaceutical Interpretation, Int. J. Pharm., 18, 25-38, 1984.

Hallquist, M., Wenger, J. C., Baltensperger, U., Rudich, Y., Simpson, D., Claeys, M., Dommen, J., Donahue, N. M., George, C., Goldstein, A. H., Hamilton, J. F., Herrmann, H., Hoffmann, T., Iinuma, Y., Jang, M., Jenkin, M. E., Jimenez, J. L., Kiendler-Scharr, A., Maenhaut, W., McFiggans, G., Mentel, Th. F., Monod, A., Prévôt, A. S. H., Seinfeld, J. H., Surratt, J. D., Szmigielski, R., and Wildt, J.: The formation, properties and impact of secondary organic aerosol: current and emerging issues, Atmos. Chem. Phys., 9, 5155-5236, doi:10.5194/acp-95155-2009, 2009.

Hilpert, K.: High-temperature Mass Spectrometry in Materials Research, Rapid Commun. Mass Sp., 5, 175-187, 1991.

Hilpert, K.: Potential of mass spectrometry for the analysis of inorganic high temperature vapors, Fresen, J. Anal. Chem., 370, 471-478, 2001.

Joback, K. G. and Reid, R. C.: Estimation of pure-component properties from group contributions, Chem. Eng. Commun., 57, 233243, 1987.

Kawamura, K., Imai,Y., and Barrie, L. A.: Photochemical Production and Loss of Organic Acids in High Arctic Aerosols During Long-Range Transport and Polar Sunrise Ozone Depletion Events, Atmos. Environ., 39, 599-614, 2005.

Kawamura, K., Kasukabe, H., and Barrie, L. A.: Source and reaction pathways of dicarboxylic acids, ketoacids and dicarbonyls in arctic aerosols: One year of observations, Atmos. Environ., 30, 1709-1722, 1996.

Kawamura, K. and Kaplan, I. R.: Motor exhaust emission as a primary source of dicarboxylic acids in Los Angeles ambient air, Environ. Sci. Technol., 21, 105-110, 1987.

Kim,Y. K. and Irikura, K. K.: Electron-impact ionization cross sections for polyatomic molecules, radicals, and ions, Proceedings of the 2nd International Conference on Atomic and Molecular Data and Their Applications, Oxford, UK, 26-30 March 2000, AIP Conf. Proc., 543, 220-241, 2000.

Koponen, I., Riipinen, I., Hienola, A., Kulmala, M., and Bilde, M.: Thermodynamic properties of Malonic, Succinic and Glutaric acids: Evaporation rates and saturation vapor pressures $\mathrm{Nu}-$ cleation and Atmospheric Aerosols, Environ. Sci. Technol., 8, 920-923, 2007.

Kundu, S., Kawamura, K., Andreae, T. W., Hoffer, A., and Andreae, M. O.: Molecular distributions of dicarboxylic acids, ketocarboxylic acids and a-dicarbonyls in biomass burning aerosols: implications for photochemical production and degradation in smoke layers, Atmos. Chem. Phys., 10, 2209-2225, doi:10.5194/acp-10-2209-2010, 2010.

Makar, P. A.: The estimation of organic gas vapour pressure, Atmos. Environ., 35, 961-974, 2001.

Mauger, J. W., Paruta, A. N., and Gerraughty, R. J.: Solubilities 
of Sulfadiazine, Sulfomidine, and Sulfadimethoxine in Several Normal Alcohols, J. Pharm. Sci., 61, 94-97, 1972.

Moller, B. Rarey, J., and Ramjugernath, D.: Estimation of the vapour pressure of non-electrolyte organic compounds via group contributions and group interactions, J. Mol. Liq., 143, 52-63, 2008.

Mønster, J. Rosenørn, T. Svenningsson, B., and Bilde, M.: Evaporation of methyl- and dimethyl-substituted malonic, succinic, glutaric and adipic acid particles at ambient temperatures, J. Aerosol. Sci., 35, 1453-1465, (and Corrigendum to "Evaporation of methyl- and dimethyl-substituted malonic, succinic, glutaric and adipic acid particles at ambient temperatures, J. Aerosol. Sci., 37, 1164, 2006), 2004.

Myrdal, P. B. and Yalkowsky, S. H.: Estimating pure component vapour pressures of complex organic molecules, Ind. Eng. Chem. Res., 36, 2494-2499, 1997.

Nannoolal, Y., Rarey, J., Ramjugernath, D., and Cordes, W.: Estimation of pure component properties Part 1. Estimation of the normal boiling point of non-electrolyte organic compounds via group contributions and group interactions, Fluid Phase Equilibr., 226, 45-63, 2004.

Nannoolal, Y., Rarey, J., and Ramjugernath, D.: Part 3. Estimation of the vapor pressure of non-electrolyte organic compounds via group contributions and group interactions, Fluid Phase Equilibr., 269, 117-133, 2008.

Pankow, J. F.: An absorption-model of gas-particle partitioning of organic-compounds in the atmosphere, Atmos. Environ., 28, 185-188, 1994.

Pankow, J. F., Seinfeld, J. H., Asher, W. E., and Erdakos, G. B.: Modeling the formation of secondary organic aerosol 1:Applications of theoretical principles to measurements obtained in the $\alpha$-pinene, $\beta$-pinene, sabinene, $\Delta(3)$-carene and cyclohexene/ozone systems, Environ. Sci. Technol., 35, 1164-1172, 2001.

Pankow, J. F. and Asher, W. E.: SIMPOL.1: a simple group contribution method for predicting vapor pressures and enthalpies of vaporization of multifunctional organic compounds, Atmos. Chem. Phys., 8, 2773-2796, doi:10.5194/acp-8-27732008, 2008.

Prausnitz, J. M., Lichtenhaler, R. N., and de Azevedo, E. G.: Molecular Thermodynamics of Fluid-phase Equilibria, Prentice-Hall Inc, New Jersey, 419, 1986.

Riipinen, I., Koponen, I., Frank, G., Hyv'arinen, A.-P., Vanhanen, J., Lihavaninen, H., Lehtinen, K., Bilde, M., and Kulmala, M.: Adipic and Malonic Acid Aqueous Solutions: Surface Tensions and Saturation Vapor Pressures, J. Phys. Chem., 111, 1299513002, 2007.
Roux, M. V., Temprado, M., and Chickos, J. S.: Vaporization, fusion and sublimation enthalpies of the dicarboxylic acids from $C_{4}$ to $C_{14}$ and $C_{16}$, J. Chem. Thermodynam., 37, 941-953, 2005.

Ribeiro da Silva, M. A. V., Monte, M. J, S., and Ribeiro, J. R.: Vapour pressures and the enthalpies and entropies of sublimation of five dicarboxylic acids, J. Chem. Thermodynam., 31, 10931107, 1999.

Ribeiro da Silva, M. A. V., Monte, M. J. S., and Ribeiro, J. R.: Thermodynamic study on the sublimation of succinic acid and of methyl- and dimethyl-substituted succinic and glutaric acids, J. Chem. Thermodynam., 33, 23-31, 2001.

Sempere, R. and Kawamura, K.: Comparative distributions of dicarboxylic-acids and related polar compounds in snow rain and aerosols from urban atmosphere, Atmos. Environ., 28, 449-459, 1994.

Solomon, S., Qin, D., Manning, M., Chen, Z., Marquis, M., Averyt, K. B., Tignor, M., and Miller, H. L. (eds.): Contribution of Working Group I to the Fourth Assessment Report of the Intergovernmental Panel on Climate Changes, Cambridge University Press, Cambridge, 2007.

Stein, S. E. and Brown, R. L.: Estimation of normal boiling points from group contributions, J. Chem. Inf. Comp. Sci., 34, 581-587, 1994.

Tsonopoulos, C.: Properties of Dilute Aqueous Solutions of Organic Solutes, Ph.D. Dissertation, University of California, CA, USA, 1970.

Wexler, A. S. and Clegg, S. L.: Atmospheric aerosol models for systems including the ions $\mathrm{H}+, \mathrm{NH} 4+, \mathrm{Na}+, \mathrm{SO} 42-, \mathrm{NO} 3-, \mathrm{Cl}-$ , Br-, and H2O, J. Geophys. Res.-Atmos., 107(D14), 4207, doi:10.1029/2001JD000451, 2002.

Yalkowsky, S. H.: Solubility and Partitioning. 5. Dependence of Solubility on Melting-Point, J. Pharm. Sci., 70, 971-973, 1981.

Zardini, A. A., Krieger, U. K., and Marcolli, C.: White light Mie resonance spectroscopy used to measure very low vapor pressures of substances in aqueous solution aerosol particles, Opt. Express, 15, 6951-6862, 2006.

Zhang, Q., Jimenez, J. L., Canagaratna, M. R., Allan, J. D., Coe, H., Ulbrich, I., Alfarra, M. R., Takami, A., Middlebrook, A. M., Sun, Y. L., Dzepina, K., Dunlea, E., Docherty, K., DeCarlo, P. F., Salcedo, D., Onasch, T., Jayne, J. T., Miyoshi, T., Shimono, A., Hatakeyama, S., Takegawa, N., Kondo, Y., Schneider, J., Drewnick, F., Borrmann, S., Weimer, S., Demerjian, K., Williams, P., Bower, K., Bahreini, R., Cottrell, L., Griffin, R. J., Rautiainen, J., Sun, J. Y., Zhang, Y. M., and Worsnop, D. R.: Ubiquity and dominance of oxygenated species in organic aerosols in anthropogenically-influenced Northern Hemisphere midlatitudes, Geophys. Res. Lett., 34, L13801, doi:10.1029/2007GL029979, 2007. 